This item was submitted to Loughborough's Research Repository by the author.

Items in Figshare are protected by copyright, with all rights reserved, unless otherwise indicated.

\title{
Students' experiences of teaching at secondary school and university: sharing responsibility for classroom engagement
}

PLEASE CITE THE PUBLISHED VERSION

http://dx.doi.org/10.1080/0309877X.2017.1332352

\section{PUBLISHER}

(c) UCU. Published by Taylor \& Francis

\section{VERSION}

AM (Accepted Manuscript)

\section{PUBLISHER STATEMENT}

This work is made available according to the conditions of the Creative Commons Attribution-NonCommercialNoDerivatives 4.0 International (CC BY-NC-ND 4.0) licence. Full details of this licence are available at: https://creativecommons.org/licenses/by-nc-nd/4.0/

\section{LICENCE}

CC BY-NC-ND 4.0

\section{REPOSITORY RECORD}

O'Brien, Breda, and Paola lannone. 2019. 'Students' Experiences of Teaching at Secondary School and University: Sharing Responsibility for Classroom Engagement”. figshare. https://hdl.handle.net/2134/23253. 
Students' experiences of teaching at secondary school and university: sharing responsibility for classroom engagement

Breda O’Brien* and Paola Iannone**

*School of Business, Waterford Institute of Technology, Waterford, Ireland, bobrien@wit.ie

${ }^{* *}$ School of Education and Lifelong Learning, University of East Anglia. UK

Dr Breda O’Brien

School of Business,

Waterford Institute of Technology,

Waterford, Ireland

bobrien@wit.ie

Dr Paola Iannone (corresponding author)

School of Education and Lifelong Learning

University of East Anglia, Norwich, NR4 7TJ

p.iannone@uea.ac.uk

Breda O'Brien is a lecturer in the Department of Accountancy \& Economics in the School of Business, at Waterford Institute of Technology, Ireland. She is an active researcher, primarily in the area of effective teaching with a particular focus on transition between school and university.

Paola Iannone is senior lecturer in educational research in the School of Education and Lifelong Learning in the University of East Anglia (now moved to the Mathematics Education Centre at Loughborough University). Her research interest is teaching and learning mathematics at university level, with particular focus on summative assessment, proof and proof production. 


\section{Students' experiences of teaching at secondary school and university: sharing responsibility for classroom engagement}

Abstract: In recent years much research has focused on student engagement, both at school and at university level. This attention is motivated by the pivotal role that engagement plays in student learning and in the student experience and retention (at university level at least). Acknowledging that student engagement is a multifaceted construct we focus on the contribution that teaching and teacher traits make to the quality of student engagement, from the student's perspective. In this small scale study we adopt a qualitative methodology to investigate in-depth students' perceptions of what factors impact on their engagement in class and what role the students themselves have in fostering such engagement. Focus group and one to one interviews with students in the last year of school and at university were analysed to reveal four overarching themes related to classroom life and student engagement including the importance of active listening from the part of both students and teachers. The Refined Quality Teaching Initiatives Framework derived from integrating findings from this study and our review of the literature outlines how dual engagement and active listening can be viable pedagogical strategies both at school and university level. The framework also brings to the fore the active role and responsibilities that students have, in their own perceptions, for engagement in the classroom. We conclude with a reflection on the implications of our findings for teacher actions in the classroom and teacher training.

Keywords: quality teaching initiatives, dual-engagement, active listening. 


\section{Introduction}

The need for high quality teachers remains a central concern in many countries (Commission of the European Communities 2007, cited in Vanassche and Kelchtermans 2014; DarlingHammond 2010). Previous research studies have addressed cognitive student outcomes in the form of learning (Kyriakides et al. 2013) and have indicated that student outcomes in the form of academic achievement vary according to their teachers (Luyten 1994; Day et al. 2007). However less is known about the effect teachers have on student engagement (Smyth and McCoy 2011). It is widely accepted that the quality of teaching is critical to student engagement (Umbach and Wawrzynski 2005) and there is a strong move towards student engagement and quality teaching initiatives to be put in place in Ireland, where the study reported in this paper took place (Hunt 2010; Smyth and McCoy 2011), and internationally (Cappon 2006, cited in Delaney et al. 2010; Organisation for Economic Co-operation and Development (OECD) 2009). Coates (2005) remarks that institutions and teachers have an obligation to provide 'the necessary conditions, opportunities and expectations' (p. 26) for engagement to occur and many scholars observe that real change to education needs to happen at a micro-level inside the classroom (Hopkins and Levin 2000; Teddlie and Reynolds 2000; Tinto 2012).

What is intended by student engagement and how this construct is understood has been the subject of much research in recent years. Newmann (1992) attempts to clarify the concept of student engagement for the student as being: 'active involvement and commitment and concentrated attention, in contrast to superficial participation, apathy and lack of interest' (p. 46). This definition recognises the importance of student-teacher relationships and 'can be considered to represent a connection in the context of a relationship which a student desires 
or expects to belong to' (Case 2007 p. 130). Bryson and Hand (2007) suggest that student engagement involves a dynamic interaction between the student and their learning environment, however such learning environment is composed of many aspects, as research by Krause and Coates (2008) suggests. Krause and Coates' (2008) study, which consisted of a survey administered to first year students in thirteen public universities in Australia, found that student engagement can be characterised by seven scales, stressing that engagement is indeed a multifaceted construct and that teaching and teachers actions are only one part of the impact of a complex learning environment. Of the scales reported in Krause and Coates' (2008) study the Student-Staff engagement scale is particularly relevant to the investigation of the role of teachers and teaching on student engagement. The authors describe the StudentStaff engagement scale as composed by three central items: empathy (from the teachers) for the students, interest (from the teachers) in student progress and teachers' skills in the classroom (ibid. p. 501). This characterisation of student engagement highlights primarily what teachers can do to promote engagement in the classroom. Indeed the relationship between teacher actions and student engagement can be determined by the student perception of how the teacher creates a successful classroom environment (Skinner and Belmont 1993). This in turn can shape the extent to which students feel part of the classroom. Such studies however do not investigate the role that students themselves perceive they have, if any, in fostering engagement in the classroom and place the responsibility for such engagement firmly on the teacher and their actions.

Moreover, studies that have investigated student engagement have mostly adopted quantitative methods using large scale surveys, such as the National Survey of Student Engagement (NSSE , Kuh 2009) and the First Year Experience Questionnaire (Krause and Coates 2008), in agreement with a behavioural perspective on this construct (Kahu 2013). 
There is however the recognised need to add a qualitative dimension to studies on student engagement to 'truly understand its nature' (Krause and Coates 2008, p 503). Moreover, Kyriakides et al. (2009) link the lack of impact of recent teaching innovations and educational reforms on student engagement to the observation that research is often at the margins of the classroom and fails to reach into the classroom to substantially improve the teacher/student experience (Teddlie and Reynolds 2000; Tinto 2012).

Our study seeks to address the need for investigation of students' perceptions of the impact of teaching on their engagement and it does so by responding to the calls for research at a micro-level inside the classroom. In designing our study we were interested in investigating student engagement from the students' perspectives and in choosing a qualitative methodology we wished to contribute to a fine grain investigation of one dimension of engagement: namely the role of teaching and teacher traits. To this aim we posed the following research questions:

RQ1: How do students conceptualise the role of interaction for classroom engagement?

RQ2: What role do teachers' traits and teaching strategies have in shaping the students' perceptions of engagement?

\section{Students' perceptions of the effect of teaching on student engagement}

To put our research into context we will synthesise existing literature on quality teacher traits and instructional practices and how these impact on student engagement drawing from existing models of teacher though process (Clark and Peterson 1986), conceptions of teaching (Kember 1997) and the act of teaching (Martin et al. 2000). In what follows, we will first summarise the research relevant to the impact of teacher actions and teacher traits on 
classroom engagement and then present its synthesis via the quality teaching framework (Figure 1.1) devised by us.

The literature acknowledges that teaching is a multifaceted activity (Stronge et al. 2011). It is characterised by a dynamic interplay between teacher, student, context and content and it is constrained by external factors relating to education. Good education, the literature suggests, is characterised by high quality learning opportunities for students. In this process 'the teacher is the most important factor for student learning' (Abell 2007 p. 1105). Therefore, efforts to improve education necessarily include efforts to improve teaching competences and to help teachers to reflect on their practices in the classroom. The literature supports the importance of quality teaching at classroom level (Teddlie and Reynolds 2000; Tinto 2012) and calls for real change in the process of interaction between teacher and student (Johnston and Watson 2004; Haggis 2006; Smyth and McCoy 2011). However Kyriakides et al. (2009) express concerns as to the lack of stimulation and enthusiasm displayed by many teachers in creating a classroom environment that will encourage students to engage.

As far back as 1979, Mehan observed that the interaction of academic knowledge and social or interactional knowledge is a necessary goal on the part of the teacher so that students can participate successfully in classroom activities. More recently, new terms have been used in the literature to denote academic and social knowledge such as teacher cognitive and affective traits (Keeley et al. 2006). Definitions of cognitive and affective teacher traits vary in the literature and here we follow Saroyan et al.'s (2004) classification. These authors note that teachers' cognitive traits include strong subject knowledge and the ability to present such knowledge clearly while being 'passionate and energetic about teaching' (White et al. 2009 p. 4). While passion can also be conceived of as an affective trait (Keeley et al. 2006), it is placed in the cognitive space in this instance due to our understanding that passion must be 
supported by strong subject knowledge in a classroom setting. The affective traits are identified as being respectful, openness towards the students, support and care (Murray 2011; White et al. 2009). Indeed, van Uden et al. (2013) notice that affective traits displayed by the teacher are a prerequisite to the successful engagement of the students before knowledge interaction can take place.

Key among effective teaching practices is the teacher-student interaction or the degree to which the teacher is able to create an environment that engages the students' attention (Hattie 2009). The teaching strategies adopted by the teacher depend on their own conceptions of teaching (Fox 1983) and may include a teacher-focused strategy, student-focused strategy and teacher-student interaction. The latter allows for dialogue, collaboration and shared learning to occur (Watkins et al. 2002; Bovill et al. 2011). Teachers' traits (Patrick 1998; van Uden et al. 2013), teaching strategies (Tinto 2002; AUSSE 2009) and teachers' conceptions of teaching therefore influence students' engagement with learning (Watkins et al. 2002). Specifically, Bovill et al. (2011) see engagement as a two way process, with both teacher and student actively involved.

Synthesising this existing literature into an explanatory quality teaching framework (Fig 1.1) we can say that the role of the teacher is pivotal to student engagement (Gorard \& See 2011). The impact of teacher traits and teacher action on student engagement is characterised by the impact that both cognitive and affective teacher traits have on such interaction and how they bring their students into this relationship (Martin et al. 2000) and that this impact is indeed the stimulus for such interaction (Gow \& Kember 1993). Acknowledging also the work of Bovill et al. (2011) results in viewing engagement both for teacher and students, and this is represented by the dual arrow in Fig 1.1. 


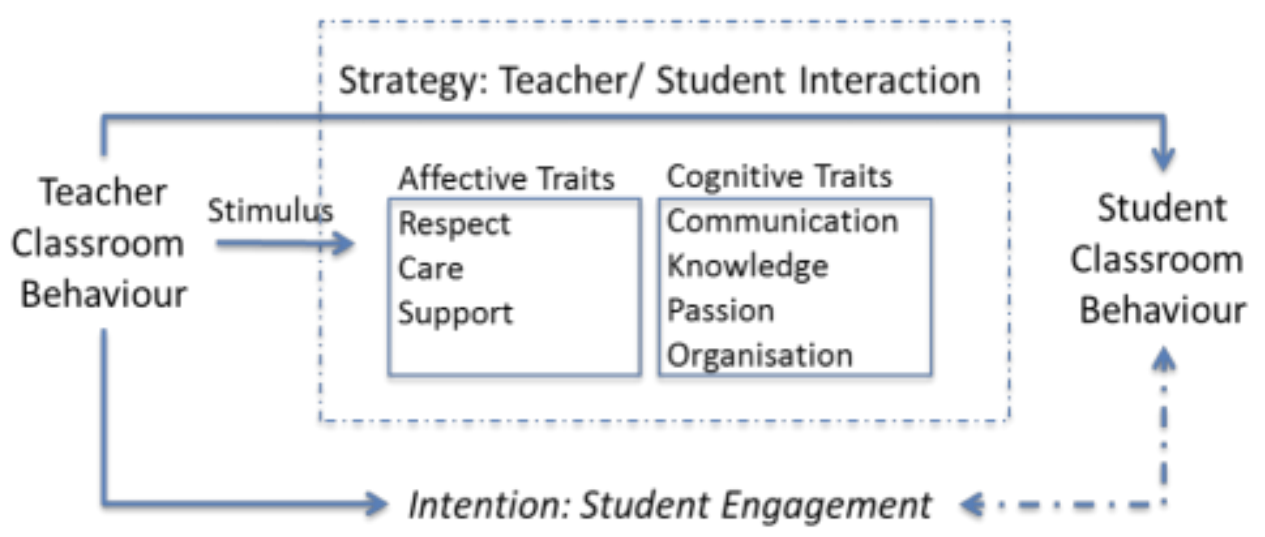

Fig 1.1: Proposed Quality Teaching Initiatives Framework

Teacher-student interaction is the desired outcome of teacher classroom behaviour and student classroom behaviour but can be difficult to achieve (Kyriakides et al. 2013). Recent studies indicate that classrooms are dominated by teacher talk (Lingard 2007) and some (Antoniou and Kyriakides 2013) suggest that student engagement could be increased by improving teachers' practices associated with the desire that students have to be part of their own student outcomes, with the teacher considering students' academic as well as social and personal needs (Stronge et al. 2011). However we know little of how students perceive their participation and responsibilities in terms of classroom engagement, with much of the literature focusing on teachers and teacher actions as stimuli (as shown in Fig 1.1).

There are many reasons reported in the literature as to why engagement in the classroom is important which are mainly related to the relationship of student engagement and student learning (Huitt 2003). Here we wish to stress one more reason: both in Ireland (where our study took place) and in the rest of Europe the number of students entering higher education has increased but drop-out rates in the first year are a particular cause of concern (Yorke and Longden 2006; Tinto 2012). The Irish Programme for Government (Government of Ireland 2011) and the European Commission (Commission of the European Communities 2007, cited in Vanassche and Kelchtermans 2014; Darling-Hammond 2010) prioritises the recruitment, 
training and support of the highest calibre teachers (Drudy 2013). This is underpinned by the strategic plan of many secondary schools and universities to provide instructional excellence to students in a positive learning environment (Jordan and O'Donnell 2013). Therefore, it is suggested that policy makers must give appropriate recognition to the importance of effective teaching for engaging students both at school and university level (Wingate 2007; Zepke and Leach 2010).

Much of the relevant literature on effective teaching has adopted quantifiable techniques measuring teacher effectiveness and student achievement (Stronge et al. 2011). More recently it has been acknowledged that in order to make a difference to educational effectiveness at a policy level researchers need to address the finer details of interactions at a classroom level (Teddlie and Reynolds 2000; Hopkins et al. 2011) and to suggest ways to improve such interactions (Reynolds et al. 2014). Therefore research that explores interactions and engagement at a classroom level (Reynolds et al. 2014), apart from student academic achievement, and that offers rich descriptions of a qualitative nature on the role of interactions between teacher and student is needed (Teddlie and Reynolds 2000, Trowler 2010). More precisely Trowler (2010) points out in her comprehensive review of the literature that engagement ultimately requires student agency, but not much is known about what influences students' participation in the learning experience. The author state that more 'exploration of the concept of student engagement from the student perspective' (p.50) is required, in order to ensure the presence of student voice.

Our study aims to address this gap and will explore the characteristics of classroom engagement from the students' perspective.

\section{Research Methods}


It is true that students are influenced by their own beliefs and the environment or institution of which they are part of, but as long as their perceptions are understood in terms of these factors then student perceptions are a valuable contribution to understand the teacher-student relationship (Rudduck and McIntyre 2007; McCoy et al. 2014) as students spend a great deal of time in class with teachers who are both good and bad (Tam et al. 2009). Therefore a purely qualitative, small-scale approach is deemed necessary to investigate the complexity of students' perceptions of teaching and of their classroom environment and to discuss those perceptions as they vary between students in their final year of secondary school and university students. The choice of involving participants all studying the same subject (accountancy in this case) was motivated by the need to keep the students' expectation of teaching comparable (Bowen 2008) as we recognise that different academic disciplines may bring different expectations from students.

Our research was conducted in four secondary schools and three universities in Ireland. The secondary school sample constituted: two all-boys schools, one all-girls school and one coeducational school. All participants were studying accounting as a subject for their final Leaving certificate examination. Their ages ranged from 17 to 19. In these schools the teachers helped in selecting participants to the study, this meant that a good range of student abilities and diversities were captured in our sample. We sought consent from the nominated pupils and their parents/guardians to participate. Before commencing data collection we spoke briefly to the students outlining what the research involved and ethical approval was obtained from the University of East Anglia in the UK where the second author was working at that time. Four group interviews (one in each school) were conducted involving 20 students in total lasting between forty and sixty minutes. 
At higher education level, three universities were selected as sites for data collection. One is an Institute of Technology (IoT) which is a university-led institution with over 10,000 students. The other two research sites are two of the largest universities in Ireland with over 30,000 students in each. All participants were studying accounting as a module on their course at the time of the study and their ages varied between 19 and 24 . Two focus groups of five and six students respectively and four single interviews were carried out in the participant institutions. The format of the interviews (whether they were focus group or oneto-one) was determined by ease of access to participants. In total 15 participants took part at higher education. Interviews with university students lasted between thirty and sixty minutes. In total, there were 35 participants across all sites in the study.

The focus group interviews were video-recorded (for ease of transcription) and the one-toone interviews were audio-recorded to allow us to conduct the interviews in a relaxed manner so as not to have to worry about who said what or take notes during the interviews (Taylor and Bodgan 1998). The semi-structured interview schedule comprised four sections. The initial questions explored background information about the students. The next section comprised questions about students' experiences of the role of interaction in the classroom. Teaching traits and teaching activities at a classroom level were then addressed. The last section explored students' experiences of their classroom environment at secondary school and at university. All interviews were fully transcribed.

We analysed the interviews following thematic analysis as proposed by Braun and Clarke (2006). The analysis commenced by focusing first on a preliminary sample of transcripts, (in this case, two transcripts - one from secondary school and one from university), reading and re-reading the actual text, comparing it to the original recorded data and attempting to assign 
codes to parts of the text alongside the margins (Burgess 1984). We looked for patterns, connections, variations within and between the texts to identify broad themes (Braun and Clarke 2006).

Text documents were created that brought together relevant coded extracts and allowed us to further study and reflect on this data. A further reflection within each code led to the emergence of sub-codes. We then re-analysed the data table of codes, sub-codes and utterances and through continued iteration between all three strands we attempted to see patterns, relationships, variations, inconsistencies and nuances emerging. The concluding element of the data analysis phase lead to the emergence of four key themes around which we structure the discussion of the data.

\section{Findings}

Four overarching themes emerge from the analysis of the interview data. These are: students' conceptualisation of the role of interaction in classroom engagement, teacher traits, instructional activities in the classroom and students' experiences of the classroom environment at secondary school and at university. In what follows we will discuss these overarching themes in turn.

\subsection{Students' conceptualisation of the role of interaction in classroom engagement}

As it is to be expected (Samuelowicz and Bain 1992; Kember 1997) students distinguish between teacher-focused teaching and student-focused teaching. Most of the university interviewees in our study report having experienced teaching predominantly as transmissive at university, a situation which is familiar to many students at this level: 
Jeff (IU) ${ }^{1}$ : $\quad 100 \%$ lecturing, there's the room, if there was no one in the room they would still be doing it [the teaching] the same way as if there was 100 people in the room. When it comes to actual teaching it's not the best.

In the interviews, students not only discuss the lack of interaction in their classroom but seem to believe, perhaps more worryingly, that the lecturers ${ }^{2}$ would not know how to change the status quo, or even that the status quo could be changed, indicating that some students may perceive their teachers as detached and completely unaware of their needs.

A similar finding occurred at two of the secondary schools in our study: teachers are perceived to be detached from their classes and generally not interested in their pupils. This characterisation of a teacher offered by a secondary school participant was not uncommon in our data:

Ivan (FGSS) ${ }^{3}$ : $\quad$ Person up at the top of the class instructing people to do work from a book or giving people information that you have to learn off.

Experience of student-focus teaching is on the other hand reported by some of the participants in secondary school. These students have seen the teacher:

Cormac (FGSS): $\quad$ Trying to get the best out of us, instructing us what to do, helping us along the way.

Some university participants have also experienced a hands-on approach by the teacher, albeit in different ways:

Noelle (FGU) ${ }^{4}$ : $\quad$ Explaining how to do it, if they don't understand taking the time to explain it in a different way to make sure they get it.

\footnotetext{
${ }^{1}$ IU: Interviewee university pseudonym

${ }^{2}$ Lecturer is a term widely used in universities in Ireland to indicate a member of staff with teaching duties - it is equivalent to the term teacher which is also used in the same context.

${ }^{3} \mathrm{FGSS}$ : Focus group secondary school pseudonym

${ }^{4}$ FGU: Focus group university pseudonym
} 
Together with these two perspectives, student-centred and teacher-centred, interestingly some of the students described a teacher-student interaction involving a shared role between teacher and student, which in turn implies shared responsibility for engagement:

Martin (FGSS): $\quad$ His [the teacher's] interaction with the class is so good and everyone works so hard in his class trying to make the most of him, make him happier, if you have that kind of desire with the people you are working with that is very important.

In order for students to get the most from teaching, respondents highlight the ability of the teacher to "turn the class around' 5 , interacting with the students by adapting their teaching and 'taking the time' to suit the needs of all students. The teacher it seems needs to be very adaptive and responsive to the classroom needs.

Focus group university participants speak very openly about this two-way interaction:

Alistair (FGU): I have always considered teaching as a very two-way street, the lecturer has to be willing to teach and give you an understanding of the subject but you have to be willing to learn and to engage in class.

And they understand that their role in this interaction brings with it a share of the responsibility:

Noelle (FGU): $\quad$ It is important for the students to engage because if you are actually doing something you are more likely to take an interest rather than if you are just sitting there.

As part of their share of the responsibility, our participants see it necessary to be very responsive to what the teacher does in the classroom and building a relationship with their teachers.

Paddy (FGU): If you see the lecturer putting a lot into it, the students are going to respect him/her for that, then they will put more effort into that subject than they would put into a subject where the lecturer is just

\footnotetext{
${ }^{5}$ Individual quotation marks represent direct quotes from the data
} 
sitting at the top of the class talking away and there is no interaction with the class.

Teachers also need to be 'understanding and flexible to what students need', and if the student 'see them [the teacher] putting in the effort you [the student] are more likely to repay them'. The teacher, as we have seen before, initiates this inclusivity. One university respondent explains:

Susan (IU): $\quad$ Yes, definitely if you are in a class with a lecturer who pays you no interest or doesn't have a plan of action or doesn't know what they are doing you are not going to put the work in as much, I find [the teacher is], not inspiring you to go home and study their subject.

Respondents at secondary school like to feel part of the class, where the teacher 'includes everyone, if you don't understand it they [the teacher] go out of their way to make sure you understand as well as everyone else does' and 'someone who is able to engage with people':

Martin (FGSS): $\quad$ Someone that makes the class more inclusive to everyone and see more interaction between everyone, and then they [the students] will put their heads down and get on with the class that's really important.

And, from the part of the teacher, our participants propose that implementing strategies to build collaboration into their classrooms will result in a more pleasant learning environment:

Noelle (FGU): $\quad$ Teachers that engage students, [you] get the feeling that they want you to do well, understand it.

We note here that the respondents not only focus on what the teacher can do to engage students in the classroom but crucially they discuss what the student can do to respond to such actions and foster engagement. This active role of the students, the respondent explain, is crucial for a successful classroom environment. 
When this is not the case, when there is no two-way interaction between teacher and students, frustration emerges, respondents feel intimidated by the teacher and would not 'dream of approaching them'. One university interviewee reports that in this case:

Brian (IU): $\quad$ No I wouldn't have any engagement whatsoever.

Similarly at secondary school, two focus groups have experienced exclusion of students in class by their teacher: 'he [the teacher] gives someone that understands, more attention', 'not approachable, not patient' and when 'he [the teacher] treats you like a child it is so frustrating'. Interestingly in the interviews, these students also describe how they cope as a group in such situations:

Martin (FGSS): $\quad$ It has brought us [the students] quite close.

Stan (FGSS): $\quad$ We teach ourselves to some extent.

Respondents at both university and secondary school offer descriptions of what the teacher and student can do to improve classroom processes and ultimately engagement of both teacher and student.

Robert (FGU): $\quad$ Students getting involved in the class rather than the teacher just standing at the top of the class telling you what to do and how to do it and the student is coming up with different ways that they can engage in class to figure it out for themselves.

For this two-way interaction to be successful in terms of student engagement participants propose that the teacher provides the stimulus that catches the students' attention.

Mick (FGU): $\quad$ Generally the teacher is the best person to initiate the students' engagement, they try and interact and not just talk in the class.

This, the students believe, requires a natural skill on the part of the teacher, as students see the teacher as being central to the success of their interaction. 
Cormac (FGSS): If I don't like the way a teacher teaches the class, it turns me off the subject and that would decide the choice of whether I would go on to do it next year or not.

Finally, the students comment that they are ready, open, flexible and willing to actively participate in class but if the teacher does not have the same agenda then the students will begin to disengage.

Mick (FGU): If they [the teachers] look like they are disconnected, you [the student] are going to disconnect as well.

However, respondents propose that 'if your point is being valued you feel you want to be part of the class and then you contribute more and you learn a lot more' and dialogue will ensue:

Neill (FGU): $\quad$ If you say, volunteer points and ask questions in class then that is going to open up a dialogue between you and the lecturer and it will flow.

\subsection{Teacher traits}

Students in our study seem to have clear ideas of what characteristics make a teacher successful. Here we have one example, together with the acknowledgment that not all teachers can have these characteristics, or appear to have these characteristics.

Declan (FGU): $\quad$ Traits conducive to a good teacher that not everyone has, you have to have patience, willing to listen, not everyone is like that.

Among the traits ascribed by the students to successful teachers we find both cognitive and affective traits. Cognitive traits we identified in our study are communication, knowledge, passion and organisation. A good teacher is one that can transform curriculum material into easily understandable, interesting material which motivates the students to want to learn:

Georgina (FGSS): I think enthusiastic, a lot of my teachers really enjoy what they are teaching and it comes across then when I am learning it, because I 
feel like she showed it to me in a way that is interesting so I want to go home now and learn this and really remember it.

Respondents at university like their lecturers to be direct and to the point. They also like the teacher to be open, easy to talk to, engaging and have the ability to listen:

Brian (IU): $\quad$ Charismatic, that would be a very good teacher, engaging, wellspoken.

All these traits, when present, will facilitate students' learning and engagement. Teachers' affective traits are also discussed in the interviews, stressing the view held by those students that teachers are important to them at an academic level but also at a social level. The affective traits mentioned in the interviews comprise respect, care and support and the students believe these traits are a prerequisite for them to successfully engage with classrooms activities. Respondents agree that respect is a key trait for a teacher but they crucially also recognise that it is a two-way process, hinting again to a shared responsibility in the classroom:

Alistair (FGU): $\quad$ They [the lecturers] are quite clear on the fact that for everyone to get the best understanding they can from the lecture, then everyone needs to have respect.

When teachers show both care and support, the students perceive the classroom environment as supportive of their needs and a place where positive relationships can ensue.

Liam (FGSS): $\quad$ Easier to communicate with them [the teachers] and learn from them if you like them rather than not like them.

In summary, students at school and university highlight teacher traits that are conducive to creating a good classroom environment where interaction takes place between teacher and students working together. Interestingly, these characteristics do not differ much across educational levels. 


\subsection{Instructional activities in the classroom}

Students have clear views on what instructional activities are appropriate and conducive to engagement and learning given specific teaching circumstances and during the interviews they give examples of both passive and active classroom environments.

Examples of passive classroom environment are experienced both at secondary school and university.
Aaron (FGSS):
He doesn't go over them, he just gives it [the answer] and we have to figure it out ourselves at night.
Jeff (IU):
She [the lecturer] moves $100 \%$ straight on, I'm in a rush... I' $m$ in a rush, I have to get here, even if you are building a foundation it makes no sense why you would move on.

On the other hand, an active classroom environment is created by good classroom management skills from the part of the teacher which allow the students to become independent learners. In this way the students have the re-assurance that if they need the teacher he/she is there and the students are confident in their teacher's ability to explain the topic and engage them in learning.

Martin (FGSS): If the teacher is fully confident on what they are doing they have no problem assigning some time to thinking differently.

Students from secondary school express the desire to become independent and critical learners:

$$
\text { Rory (FGSS): } \quad \text { Think outside the box and be challenged. }
$$

Students believe that when teachers have a clear idea of the goals they have set out together with the students in a collaborative way, actively listening to students, seeing the lesson through the eyes of students, then true engagement occurs for both teacher and students. 
Susan (IU): $\quad$ Organised, concise, listens to us, prepared to answer questions over and over again, can lead the class well steer us all in the right direction. For me it's all about being organised and know your teaching plan and accomplishing it with the class.

Noelle (FGU): $\quad$ Constant interaction means you are going to be involved in the class [and] it's much easier to learn when it's that way.

One important point of working in a collaborative way that the students value is the belief that they are listened to but this is not just listening and moving on from the part of the teacher: it is listening and then acting on the pupils' interventions. Our data suggests the idea of active listening as crucial on the part of both teacher and student, and this reinforces the perception that responsibility for an engaging and effective classroom must be shared by teacher and students:

Robert (FGU): $\quad$ It feels better when they [teachers] do listen to you because you will be more inclined to ask a question rather than asking a question to a lecturer who doesn't want to listen and you feel stupid.

In a classroom where teachers actively listen to their students, dialogue will ensue and students will be willing and ready to engage in working collaboratively:

Neill (FGU): $\quad$ If you say, volunteer points and ask questions in class then that is going to open up a dialogue between you and the lecturer and it will flow. If you keep on volunteering and the lecturer answers, it will help speed up the flow of the lecture and sometimes I find where there is that sense of dialogue in class the time just flies by.

Part of the two-way interaction we have seen emerging from the students' comments is the importance they ascribe to the feedback they receive from the teacher, not only in academic terms of what the students need to do to improve but also as supportive and encouraging comments:

Georgina (FGSS): When she is handing back things she would say that was very good, that was good but you need to work on here or here, she would always give you constructive criticism as well, she is very encouraging. 
In contrast, respondents who reported that they had experienced a very passive environment at university level explain that the teacher would give a quick summary of work done in previous class for about 20 seconds and then 'just reads out slides and bore everyone to tears', while 'she [the lecturer] just stands there watching us' and makes no attempt to help students that may be in difficulty. In their perception students are not given an opportunity to provide feedback so the lecturer 'doesn't know whether we actually understood or not'.

\subsection{Students' experiences of classroom environment at secondary school and university}

The data we collected for our study hints to the perception that teachers are in a prime position to really make a difference for students' engagement both at secondary school and at university. University participants believe that lecturers have a profound impact on students and the choices that they make during their studies:

Jeff (IU): $\quad$ No, my accounting lecturer wouldn't inspire me to go on and do accounting.

Our study also found differing teaching strategies to exist at both university and secondary school levels. Respondents point to a mismatch in the teaching environments of school and university level and a lack of enjoyment for students in the final years of school. Secondary school participants describe the system they are experiencing as largely mark-driven:

Martin (FGSS): It is too exam-dictated, [I] want more understanding of what's happening and real-life, understanding that would make it much more interesting.

Whereas at university the lecturer is more a:

Alistair (FGU): Font of knowledge and you [the student] have to go to them [the lecturer] to look for knowledge. 
Experiences across participants at university are not uniform, indicating that there is variation in teaching approaches also in this context, contrary to the belief often held by the students that teaching will be uniformly driven by lectures. This student for example did not expect a collaborative approach at university but

Declan (FGU): $\quad$ Constant interaction means you are going to be involved in the class.

Other university students comment on the surprise at being required to organise their learning and moving towards being independent learners, as well as losing the direct knowledge of the teacher they had in secondary school.

Susan (IU): It's like they don't even remember teaching us, there is nothing worse than that.

While at secondary school level respondents remarked that:

Cormac (FGSS): You have only spoon-feeding, it's all the same stuff, they [the teachers] know it off by heart at that stage.

These comments seem to indicate that the transition between school and university is made difficult by the lack of fostering of independent thinking at school level, which can happen in an assessment-driven school system and the sudden requirement of university studies for independence and self-organisation. Moreover, comments such as the one we reported would indicate that students have thought about issues related to transition and that the difficulties they encounter affect them deeply and possibly stifle their creativity as independent thinkers. It transpires from our data that both university and secondary school students have high aspirations as learners and want to achieve:

Brian (IU): The people that are getting the best results at the end of the day are the people who work independently. 
What is also clear is that in many cases students do not feel that that the classroom environment helps them.

\section{Discussion}

Our data shows that students' reflections on teaching at university and at secondary school revolve around four overarching themes: students' conceptualisation of the role of interaction in classroom engagement, teacher traits, instructional activities in the classroom and students' experiences of the classroom environment at secondary school and university. Findings in the latter three categories reflect themes which are also found in the literature and were included in our synthesis in Fig 1.1. Findings related to the role of classroom interaction will help us refine the Framework in Fig 1.1., adding to this a new focus on students' responsibility for classroom engagement and will contribute to our understanding of the characteristics of teacher-student engagement (as proposed in Krause and Coates 2008).

The data suggests that the experiences of both school and university participants are mixed. Some university participants perceive their lecturers to be engaging, interactive and using a hands-on approach to teaching. In contrast, others have experienced little interaction with their lecturers who 'stand behind their podium reading off slides'. This experience is in stark contrast with students' desire to be actively involved in their lectures (see also Boulton-Lewis et al. 2001 and King 2013). This involvement, the students believe, would make the subject more enjoyable and would encourage them to attend classes. This variety of experiences also signals that it is indeed possible to have a hands-on approach to university teaching and some of the literature has suggested successful uses of more interactive teaching in large classes at university level (See for example the case of flipped classrooms, Phillips and Trainor 2014). At secondary school teaching can be very interactive and the teachers are often seen to be able to adapt their strategies if students are not engaged. Crucially, our respondents perceive 
this interaction to be a two-way process with this responsibility resting with the students as much as with the teachers. The focus on student responsibility for engagement refines findings from quantitative tools that suggested engagement is mostly the teacher's responsibility (Krause and Coates 2008). Indeed, as it transpires from our data, students want to be actively part of the classroom experience with the teacher considering students' academic as well as social and personal needs (Stronge et al. 2011). This resonates with findings regarding students' wish to 'fit in' when they are interacting with supportive teachers (Johnson and Watson 2004), but our findings also support the idea that with the twoway interaction comes the realisation on the part of the students that they share responsibility for this process. This reflects Devine et al's. (2013) findings that for good teaching to take place there must be active participation and engagement of student and teacher, which in turn results in effective learning (Biggs 2003). Therefore, while Gorard and See (2011) and Hattie (2012) were amongst the first to propose listening as an important teaching factor for student engagement, our data suggests the importance of active listening intended as a responsibility of both teacher and student and as an important determinant of the success of the teacherstudent interaction process.

In our study the term active listening, borrowing from Gordon (1977) who first adopted it, denotes the positive student/teacher two-way interaction students refer to as a necessary part of successful engagement. Our findings suggest that it is this active listening on the part of both teacher and student as they reflect on one another's questions, ideas and feedback that enriches the classroom environment and fosters student engagement, therefore adding the student dimension to this interaction. University students confirm that integration and successful transition can take place in the classroom setting (Tinto 1993) and respondents from our study agree 'that if you have a good lecturer interested in their students', 'if you enjoy the classes', 'like the lecturer, you are going to want to attend class'. 


\subsection{The Refined Quality Teaching Initiatives Framework}

The emphasis that our data has put on the role of the students in shaping classroom engagement and the emergence of the idea of active listening suggest a revision of the quality teaching framework we had derived from the existing literature (see Fig 1.1). We report this revised framework in Fig 2.1 below. The Refined Quality Teaching Initiatives Framework (Fig 2.1) aims at synthesising existing literature and the findings of our own data relating to student engagement in the classroom. It is intended as an interpretative tool for classroom interaction, advancing the theoretical analysis of the social dimension of student engagement (Kahn, 2014), rather than through the previously referenced behaviourist perspective (Kahu 2013). Fig 2.1 adds to our previous synthesis (reported in Fig 1.1) emphasising two of the characteristics needed for such engagement; active listening and dual interaction.

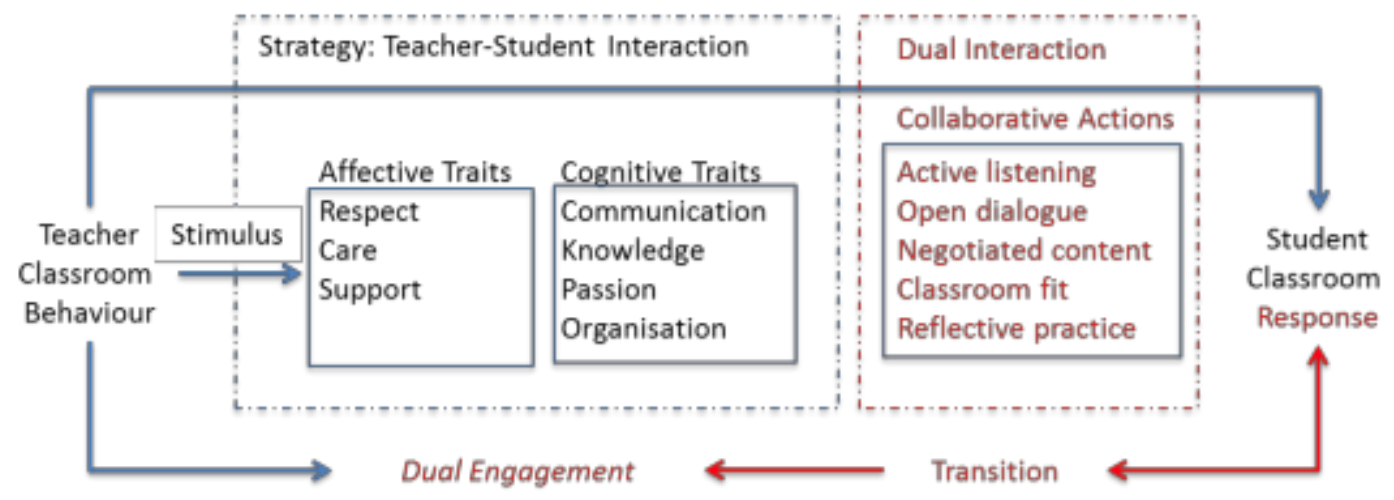

Figure 2.2. Refined Quality Teaching Initiatives Framework Fig 2.1: Refined Quality Teaching Initiatives Framework

Previous literature on student engagement (which we synthesised in the framework in Fig 1.1), consisted mainly in results from a behaviourist perspective on student engagement (Kahu 2013) emerging from the use of large surveys to measure such engagement (such as the NSSE). This literature focused on one particular aspect of engagement related to the 
impact of teachers and teaching as described by Krause and Coates (2008). Through the use of a fine grained qualitative methodology we have been able to add a more social dimension to Fig 1.1 which has emerged from the emphasis that students put on the social form of interaction with the teacher and their own responsibilities for engagement. The focus of the framework is on students and teacher negotiating classroom interaction through active listening which allows for depth of thinking and requires genuine dialogue between the teacher and the student (Hattie 2012). This in turn models dual-interaction and mutual respect for both teachers' and students' perspectives allowing for collaboration to occur and influences students' engagement (Watkins et al. 2002).

The Refined Quality Teaching Initiatives Framework has been devised to be faithful to the language of the students. Since few empirical studies of this nature are available, the current study describes students' experiences of the type of teacher behaviour demonstrated in the classroom and contributes to suggestions of how real improvements can be made by teachers to their teaching practices and students in their interaction practices. One of the key elements of our findings is the suggestion that the quality teaching initiatives recommended are equally both viable and desirable across different education levels (Kyriakides et al. 2013) as proposed in the Refined Quality Teaching Initiatives Framework.

Our data supports some implications for teaching aimed to foster engagement. These are mostly related to reinforcing the importance of a reflective practitioner angle both in initial teacher training and professional development for teachers. For example fostering appreciation of the students' perspective, reflecting on teacher-student interaction in the classroom, promoting continuous professional development programmes which encompass both pedagogical engagement strategy training as well as social engagement strategy training, and encouraging dialogue and collaboration in classrooms at all points are examples of how engagement can be fostered. Our findings have also implications for policy implementations. 
These, to date, have focused on teacher cognitive knowledge rather than affective teacher classroom behaviour (Beach 2011). Current research (Hattie 2012) and findings from our own study suggest that the focus of educational policy should shift from teacher cognitive knowledge to teacher as reflective practitioner. This will allow the teacher to adapt and innovate when teaching strategies are not succeeding, have a high level of flexibility and become 'adaptive learning experts' (Hattie 2012 p. 25).

\subsection{Limitations of the study}

Collectively the small sample size of 35 participants involved in ten interviews and a nonprobability approach to participant selection means that the generalisability of the findings of our study is understandably limited. It is worth noticing however that there is evidence (Guest et al 2006) indicating that when analysing interviews seeking overarching themes emerging from the data in a homogeneous sample, at least $80 \%$ of the main themes are likely to emerge from the first 6 interviews. This does not mean that our small sample can offer a definitive answer to our research questions, or that it is widely generalizable outside the context in which the study was carried out. However, we believe that our findings are adequate for an exploratory study and can suggest novel aspects of an under-researched area that can have general relevance. Indeed, the strength of the current study lies in its 'emergent nature, its ability to go with the flow rather than control it' (Padgett 1998 p. 20). As a result, the student voice emerges from this study very clearly and the findings reflect the participants' perceptions and the importance that those have on classroom engagement.

\section{Concluding remarks}

The current study set out to explore students' perceptions of teacher traits and teaching on classroom engagement at secondary school and at university taking a fine grained, qualitative approach. As a finding of our research we have suggested a refined understanding of the 
impact that teacher traits and teacher actions have on student engagement and the importance that students play in such engagement. The key message from our findings is that education stakeholders need to examine the impact of teaching strategies on student development in a holistic way, not only in terms of learning, but in terms of the overall social development of the students. It has also brought to the fore the idea that engagement in the classroom can only happen if there is a shared responsibility between teacher and students for such engagement. Our study suggests further directions for research. Future research may focus on investigating the transferability of the Refined Quality Teaching Initiatives Framework to contexts other than the context of study. A longitudinal study that explores students and teachers overtime following the use of the Refined Quality Teaching Initiatives Framework as the analytical lens may test the effectiveness of the model. Additional research, is also needed to extend and deepen teachers' understanding of professional practice that is interrelated with performance and development of that practice.

[7553 words]

\section{References}

Abell, S. K. 2007. Research on science teacher knowledge. Handbook of research on science education, edited by S. K. Abell, and N.G. Lederman, 1105-1149, Mahwah, New Jersey: Lawrence Erlbaum Associates, Publishers.

Antoniou, P. and L. Kyriakides. 2013. A dynamic integrated approach to teacher professional development; impact and sustainability of the effects on improving teacher behaviour and student outcomes. Teaching and Teacher Education, 29: 1-12.

AUSSE 2009. Australian survey of student engagement engaging students for success: Australian student engagement report, Melbourne, Australian council for educational research. Available from: http://www.acer.edu.au/ausse/, [Accessed Sept 2013].

Beach, D. 2011. Education science in Sweden: promoting research for teacher education or weakening its scientific foundations? Education Inquiry, 2(2): 207-220.

Biggs, J. 2003. Teaching for Quality Learning at University, (2 ${ }^{\text {nd }}$ Ed.), The Society for Research into Higher Education and Open University Press, Edmunds: St Edmundsbury Press. 
Boulton-Lewis, G.M., Smith, D.J.H., McCrindle, A.R., Burnett, P.C. and Campbell, K.J. (2001) Secondary teachers' conceptions of teaching and learning, Learning and Instruction, 11(1): 35-51.

Bovill, C., A. Cook-Sather and P. Felten. 2011. Students as co-creators of teaching approaches, course design and curricula: Implications for academic developers. International Journal for Academic Development, 16(2): 133-145.

Bowen, G.A. 2008. Naturalistic inquiry and the saturation concept: A research note. Qualitative Research, 8(1): 137-152.

Braun, V. and V. Clarke. 2006. Using thematic analysis in psychology. Qualitative Research in Psychology, 3(2): 77-101.

Bryson, C. and L. Hand. 2007. The role of engagement in inspiring teaching and learning. Innovations in Education and Teaching International, 44: 349-62.

Burgess, R. G. 1984. In the Field: An Introduction to Field Research. London: Unwin Hyman.

Case, J. 2007. Alienation and engagement: exploring students' experiences of studying engineering. Teaching in Higher Education, 12(1): 119-133.

Clark, C.M. and P.L. Peterson. 1986. Teachers' Thought Processes. In Handbook of Research on Teaching third edition, A project of the American Educational Research Association. edited by M. Wittrock, New York: MacMillan.

Coates, H. 2005. The value of student engagement for higher education quality assurance. Quality in Higher Education, 11(1): 25-36.

Coates, H. 2007. A model of online and general campus-based student engagement. Assessment \& Evaluation in Higher Education, 32: 121-41.

Darling-Hammond, L. 2010. Teacher education and the American future. Journal of Teacher Education, 61(1-2): 35-47.

Day, C., P. Sammons, G. Stobart, A. Kington and Q. Gu. 2007. Teachers Matter: Connecting Work, Lives and Effectiveness. Milton Keynes: Open University Press.

Delaney, J., T. Johnston, A. Johnston, T. Dennis and D. Treslan. 2010. Student perceptions of effective teaching in Higher Education. Available from:

http://www.unwex.edu/disted/conference, [Accessed: Feb 2013].

Devine, D., D. Fahie and D. McGillicuddy. 2013. What is good teaching? Teacher beliefs and practices about their teaching. Irish Educational Studies, 32(1): 83-108.

Drudy, S. (2013). What is good teaching? What makes a good teacher? In O' Toole, F. (2013) Why education matters, the importance of education to Ireland's economy and society, CRM publications, Dublin.

Fox, D. 1983. Personal theories of teaching. Studies in Higher Education, 8(2), 151-163. 
Gorard, S. 2002. Fostering scepticism: the importance of warranting claims. Evaluation and Research in Education, 16(3): 136-149.

Gorard, S. and B.H. See. 2011. How can we enhance enjoyment of secondary school? The student view. British Educational Research Journal, 37(4): 671-690.

Gordon, T. 1977. Leader Effectiveness Training, New York: Wyden books.

Government of Ireland 2011. Programme for Government 2011. Available from: http://www.taoiseach.gov.ie/eng/Publications/Publications_2011/, [Accessed Oct 2013].

Gow, L. \& Kember, D. 1993. Conceptions of teaching and their relationship to student Learning, British Journal of Educational Psychology, 63: 20-33.

Guest, G., Bunce, A., \& Johnson, L. 2006. How many interviews are enough? An experiment with data saturation and variability. Field methods, 18(1), 59-82.

Haggis, T. 2006. Pedagogies for diversity: Retaining critical challenge amidst fears of 'dumbing down'. Studies in Higher Education 31(5): 521-35.

Hattie, J. 2009. Visible learning, New York: Routledge.

Hattie, J. 2012. Visible learning for teachers: maximising impact on learning, Routledge, London.

Hopkins, D. and B. Levin. 2000. Government policy and school improvement, School Leadership and Management, 20(1): 15-30.

Hopkins, D., J. Munro and W. Craig. 2011. Powerful learning: A strategy for systemic educational improvement. Melbourne: ACER.

Huitt, W. (2003) A transactional model of the teaching/learning process. Educational Psychology Interactive, Valdosta, GA: Valdosta State University. Available from: http://www.edpsycinteractive.org/materials/tchlrnmd.html, [Accessed Sept 2013].

Hunt, C. 2010. National strategy for Higher education. Available from: http://www.irishtimes.com/focus/2011/hunt-report, [Accessed Feb 2014].

Johnson, G.C. and G. Watson. 2004. Oh Gawd, How am I Going to Fit Into This? Producing [Mature] First-year Student Identity. Language and Education, 18(6): 474-487.

Jordan, E. and R. O’ Donnell. 2013. Developmental welfare requires quality, standards and accountability in Irish education. In Why education matters, the importance of education to Ireland's economy and society, edited by F. O'Toole, CRM publications, Dublin.

Kahn, P.E., 2014. Theorising student engagement in higher education. British Educational Research Journal, 40(6), pp.1005-1018.

Kahu, E.R., 2013. Framing student engagement in higher education. Studies in Higher Education, 38(5), pp.758-773. 
Keeley, J., D. Smith and W. Buskist. 2006. The teacher behaviors checklist: Factor analysis of its utility for evaluating teaching. Teaching of Psychology, 33: 84-91.

Kember, D. 1997. A reconceptualisation of the research into university academics' conceptions of teaching. Learning and Instruction, 7(3): 255-275.

King, P. (2013) Supporting high quality teaching in O' Toole, F. (2013) Why education matters, the importance of education to Ireland's economy and society, CRM publications, Dublin.

Krause, K.L. and Coates, H., 2008. Students' engagement in first-year university. Assessment \& Evaluation in Higher Education, 33(5), pp.493-505.

Kuh, G.D., 2009. The national survey of student engagement: Conceptual and empirical foundations. New Directions for Institutional Research, 2009(141), pp.5-20.

Kyriakides, L., B.P.M. Creemers and P. Antoniou. 2009. Teacher behaviour and student outcomes: Suggestions for research on teacher training and professional development. Teaching and Teacher Education, 25: 12-23.

Kyriakides, L., C. Christoforou and C. Y. Charalambous. 2013. What matters for student learning outcomes: A meta-analysis of studies exploring factors of effective teaching. Teaching and Teacher Education, 36: 143-152.

Lingard, B. 2007. Pedagogies of indifference. International Journal of Inclusive Education, 11(3): 245-266.

Luyten, H. 1994. Stability of School Effects in Dutch Secondary Education. International Journal of Educational Research, 21 (2): 197-216.

McCoy, S., E. Smyth, D. Watson and M. Darmody. 2014. Leaving school in Ireland: A longtitudinal study of post school transitions. Available from:

http://www.esri.ie/UserFiles/publications/RS36.pdf [Accessed Aug 2014].

Martin, E., M. Prosser, K. Trigwell, P. Ramsden and J. Benjamin. 2000. What university teachers teach and how they teach it. Instructional Science, 28: 387-412.

Mehan, H. 1979. Learning Lessons: Social organization in the classroom. Cambridge, MA: Harvard University Press.

Murray, S. (2011) Secondary students' descriptions of "good" mathematics teachers, Australian Mathematics Teacher, 67(4): 14 - 21.

Newmann, F.M. 1992. Student Engagement and Achievement in American Secondary Schools. New York: Teachers College Press.

OECD 2009. Creating Effective Teaching and Learning Environments: First Results from TALIS. Paris: OECD. Available from: http://www.oecd.org, [Accessed Jul 2013].

Padgett, D.K. 1998. Qualitative methods in social work research, challenges and rewards. Sage publications, Thousand Oaks. 
Patrick, K. (1998) Teaching and Learning: The Construction of an Object of Study. Melbourne: The University of Melbourne.

Phillips, C. R., and J. Trainor. 2014. Millennial students and the flipped classroom. Journal of Business and Educational Leadership, 5(1): 44-49.

Reynolds, D., P. Sammons, B. De Fraine, J.V. Damme, T. Townsend, C. Charles Teddlie and S. Stringfield. 2014. Educational effectiveness research (EER): a state-of-the-art review. School Effectiveness and School Improvement: An International Journal of Research, Policy and Practice, 25(2): 197-230.

Rudduck, J. and D. McIntyre. 2007. Improving Learning Through Consulting Pupils. London: Routledge.

Samuelowicz, K. and J. Bain. 1992. Conceptions of teaching held by academic teachers, Higher Education. 24(1): 93-111.

Saroyan, A., Amundsen, C., McAlpine, L., Weston, C., Winer, L. \& Gandell, T. (2004) Assumptions underlying workshop activities. In Saroyan, A. \& Amundsen, C. (Eds.), Rethinking Teaching in Higher Education: pp. 15-29, Sterling, VA: Stylus.

Skinner, E.A. and M.J. Belmont. 1993. Motivation in the Classroom: Reciprocal Effects of Teacher Behavior and Student Engagement Across the School Year. Journal of Educational Psychology, 85 (4): 571-581.

Smyth, E. and S. McCoy. 2011. Improving Second Level Education: (2011), ESRI Renewal Series Paper 5: 1-36. Available from: https://www.esri.ie/UserFiles/publications/EC005.pdf, [Accessed Sept 2012].

Stronge, J.H., T.J. Ward and L.W. Grant. 2011 What Makes Good Teachers Good? A CrossCase Analysis of the Connection between Teacher Effectiveness and Student Achievement. Journal of Teacher Education 62(4): 339-355.

Tam, K.Y., M.A. Heng and G.H. Jiang. 2009. What undergraduate students in China say about their professors. Teaching in Higher Education, 14(2): 147-159.

Taylor, S. J. and R. Bogdan. 1998. Introduction to Qualitative Research Methods, (3rd Ed.). NY: Wiley.

Teddlie, C. and D. Reynolds. 2000. The international handbook of school effectiveness research. London: Falmer Press.

Tinto, V. 1993. Leaving University: Rethinking the causes and cures of student attrition (Second Edition). Chicago: University of Chicago Press.

Tinto, V. 2002. Establishing Conditions for Student Success. In: 11th Annual Conference of the European Access Network, Monash University, Prato, Italy. URL. Available from: http://www.wmin.ac.uk/ean/wpm\$5de1.pdf [Accessed May 2012].

Tinto, V. 2012. Enhancing student success: Taking the classroom seriously. The International Journal of the First year in Higher Education, 3(1): 1-8. 
Trowler, V. 2010. Student engagement literature review, The higher education academy, Available from http://www-

new2.heacademy.ac.uk/assets/documents/studentengagement/Student Engagement LiteratureReview.pdf [Accessed Jan 2015].

Umbach, P.D. and Wawrzynski, M.R., 2005. Faculty do matter: The role of college faculty in student learning and engagement. Research in Higher Education, 46(2), pp.153-184.

Vanassche, E. and G. Kelchtermans. 2014. Teacher educators' professionalism in practice: Positioning theory and personal interpretative framework. Teaching and Teacher Education, 44: 117-127.

van Uden, J.M., H. Ritzen and J.M. Pieters. 2013. I think I can engage my students. Teachers' perceptions of student engagement and their beliefs about being a teacher. Teaching and Teacher Education, 32: 43-54.

Watkins, C., E. Carnell, C. Lodge, P. Wagner and C. Whalley. 2002. Effective Learning. London, Institute of Education, National School Improvement Network Research Matters series No.17.

White, B., Barnes, A., Lawson, M. \& Johnson, W. (2009) Student perceptions of what makes good teaching. Refereed paper presented at the annual conference of the Australian Teacher Education Association, Albury, 28 June-1 July, Available from: http://atea.edu.au/ConfPapers/2009/Refereed/BWhite.pdf, [Accessed Sept 2014].

Wingate, U. 2007. A Framework for transition: Supporting 'Learning to Learn' in Higher Education. Higher Education Quarterly, 61(30): 391-405.

Yorke, M. and B. Longden. 2006. The vital first year. Academy Exchange, 4(1): 16-7.

Zepke, N. and L. Leach. 2010. Improving student engagement: Ten proposals for action. Active Learning in Higher Education, 11(3): 167-177. 